\section{US Senate bills on cloning under fire from researchers}

[WASHINGTON] Professional organizations representing US biomedical researchers launched a concerted attack last week on proposed cloning legislation as debate began on two bills in the Senate.

The Federation of American Societies for Experimental Biology (FASEB) described one of the bills, written by Republicans, as "damaging to worthwhile research". The Association of American Medical Colleges (AAMC) argued against any legislation, favouring a voluntary moratorium.

On 2 February, Senators Dianne Feinstein (Democrat, California) and Edward Kennedy (Democrat, Massachusetts) introduced a bill that would enact a ten-year moratorium on cloning for reproductive purposes, although allowing the cloning of human embryos that are not implanted. Breaches would be punished by civil fines.

The following day, Senators Christopher Bond (Republican, Missouri), Bill Frist (Republican, Tennessee) and Judd Gregg (Republican, New Hampshire) introduced a bill that would place a permanent ban on all forms of human cloning - including the cloning of human embryos that are not implanted. This bill bans "taking the nuclear material of a human somatic cell and incorporating it into an ooctye from which the nucleus has been removed or rendered inert and producing an embryo". Breaches would be punished by up to ten years in prison and civil fines.

In defending the Democratic bill, Feinstein argued that "the key is not to stop the technology [but] to stop the implantation of the embryo produced by this technology in a human uterus". She added that "virtually all the scientific community supports Feinstein-Kennedy and opposes Bond-Frist".

Frist argued that his bill would not impede research, but would prevent the "creating of warehouses of human embryos solely for research, and ultimately destruction".

More than $\mathbf{7 0}$ groups signed a letter sent by the AAMC on Monday (9 February) to senators urging them to avoid legislating, and seeking instead a voluntary five-year moratorium on research. The proposals in Congress "would have a chilling effect on vital areas of research that could prove of enormous public benefit," said the letter. It argued that the Food and Drug Administration's plan to police cloning through existing regulations on biological products "effectively protects the public" (see Nature 391, 318; 1998).

In a separate letter to Senator Connie Mack (Republican, Florida), the American Association for Cancer Research urged a 45-day delay on any legislative activity on cloning.

M.W.

\title{
Population explosion raises alarm over lab animal health
}

[WASHINGTON] Burgeoning animal populations in US research facilities are threatening valuable animal disease models, warns the country's National Research Council (NRC). It is therefore calling for an expansion of animal holding capacity.

The NRC report Biomedical Models and Resources says overcrowding is posing a grave threat to the health and preservation of disease models. This overcrowding, says the report, is due to exploding populations of transgenic and knockout mice, the increased use of animals in research generally, and increased inter-institutional traffic and declining health surveillance. These factors have created "dry tinder for devastating [infectious disease outbreaks] among irreplaceable animal colonies".

As a result, the council is calling "urgently" for funding of new building to expand animal-holding capacity in research institutions, and for specialized buildings — such as the biocontainment facilities used in infectious disease research - that could be shared between researchers at different institutions.

"There's a desperate need for increased animalbreeding space," says Muriel Davisson, director of genetic resources at the Jackson Laboratory in Bar Harbor, Maine, and chair of the panel that wrote the report. She urges that the fundamental need for space, diagnostic support and training should not "get lost in the glamour of specific animal models".

The report, compiled for the National Center for Research Resources (NCRR) at the National Institutes of Health (NIH), was released at a meeting of the NCRR's Advisory Council last month. Its six authors surveyed more than 70 investigators at NIH and elsewhere in compiling their recommendations, which are intended to help long-term planning at NCRR, the key supporter of animal research facilities through the NIH.

The NCRR director, Judith Vaitukaitis, calls the report - which also made recommendations on animal use ranging from training of scientists to cryopreservation of animal model embryos - "very thoughtful". She adds that the magnitude of the problem is immense and "going to get much worse."

Anecdotal evidence points to several causes for the crisis, says the report. For example, increasing mouse populations since 1980 have swollen animal numbers far beyond the level for which institutions were prepared. Also, the upgrading of standards for animalholding facilities decreases the amount of space institutes can provide for each dollar. And animals are increasingly being shared by investigators at different institutions, so the risk of disease transmission has become

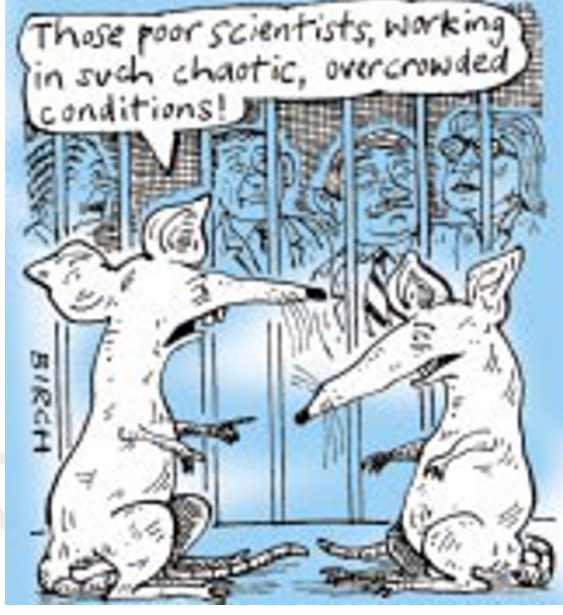

greater at a time when there are declining funds for testing for subclinical diseases. "Our laboratory animal infectious disease guard appears to be down," the report says.

Vaitukaitis says that, as a first step in responding to the situation, the NCRR is planning to establish regional centres for receiving, cryopreserving and distributing animals in the west, midwest and south of the United States. These centres would also develop specialties, for instance in models for cancer, or immunology-related research. The centres would complement the northeast's Jackson Laboratory, a unique facility that selects, cryopreserves, maintains and distributes genetically engineered mice. Such specialized centres, it is hoped, would ensure clean animal stocks.

Elsewhere, Vaitukaitis plans to focus money on training veterinarians to carry out molecular genetics, with the aim of getting them to instruct other investigators who treat animals like "four legged test-tubes", she says.

But NCRR's ability to deal with a nationalscale problem remains limited, despite the hefty 13.4 per cent increase proposed in President Bill Clinton's 1999 budget plan. The centre's \$108 million 1999 budget for all work on animal disease models and facilities contains just \$7.8 million for improvement of animal facilities - merely 1.5 per cent of the total proposed spending on NCRR for 1999. Within a separate, \$20 million programme for general research construction, NCRR is seeing a steady rise in applications for funds to upgrade and enlarge animal facilities, primarily for holding knockout and transgenic mice.

Vaitukaitis says, nonetheless, that NCRR's aim remains to "significantly increase the current capacity" for animals in the nation's research facilities. Another goal, she says, is "to keep working with investigators out there to make sure we're responsive to the roadblocks that they see".

Meredith Wadman 